Ksenija Vuković*

Ivana Fojs **

Kristina Detelj ${ }^{* * *}$
JEL klasifikacija: L26, O34, Z11

Prethodno priopćenje

https://doi.org/10.32910/ep.72.4.5

\title{
KONVERZIJE KAPITALA PODUZETNIKA U KREATIVNIM I KULTURNIM INDUSTRIJAMA SJEVEROZAPADNE HRVATSKE
}

Ciljevi ovog rada su identificirati vrste kapitala koje koriste poduzetnici u kreativnim i kulturnim industrijama u Hrvatskoj te ispitati mogućnosti konverzije kapitala iz jednog oblika u drugi. Teorijski okvir istraživanja je Bourdienova teorija kapitala u kojoj se kapital pojavljuje u četiri forme: ekonomski, kulturni, socijalni i simbolički kapital. Da bi se odgovorilo na postavljeno istraživačko pitanje koristi se interpretativna paradigma, a kao primarni istraživački alat koristi se fenomenološko intervjuiranje. Provedeno je dubinsko intervjuiranje 10 poduzetnika. Rezultati istraživanja ukazuju na raznolike prakse korištenja kapitala poduzetnika te značajne mogućnosti konverzije kapitala. Visoki stupanj konverzije kapitala prisutan je kod kulturnog i socijalnog kapitala.

Ključne riječi: Bourdieuova teorija kapitala, kreativne i kulturne industrije, poduzetnici, fenomenološki pristup

* K. Vuković, dr. sc., redovita profesorica, Sveučilište u Zagrebu, Fakultet organizacije i informatike (e-mail: ksenija.vukovic@foi.hr).

** I. Fojs, mag. oec., asistentica, Sveučilište u Zagrebu, Fakultet organizacije i informatike (e-mail: ivfojs@foi.hr).

**** K. Detelj, dr. sc., docentica, Sveučilište u Zagrebu, Fakultet organizacije i informatike (e-mail: kristina.detelj@foi.hr). Rad je primljen u uredništvo 02.02.2018. godine, a prihvaćen je za objavu 21.08.2018. godine. 


\section{UVOD}

Empirijska istraživanja koja se istodobno odnose na više vrsta kapitala su rijetka (Karataş-Özkan, 2011.; Shaw, Gordon, Harvey i Maclean, 2013.), a istraživanja o konvertibilnosti kapitala još su u ranoj fazi (Pret, Shaw i Drakopoulou Dodd, 2016.). U istraživanju poduzetništva u recentnije vrijeme moguće je opaziti poziv istraživačima za korištenjem novih metoda i različitih istraživačkih paradigmi (Shepherd, 2015.) s obzirom na to da poduzetništvo predstavlja ekonomski i društveni fenomen koji nije moguće razumjeti korištenjem monometodskog pristupa (Aldrich, 1992.). Ovo istraživanje na tragu je tog poziva da se razvojem istraživačkog polja poduzetništva koriste alternativni pristupi i kvalitativne metode u istraživanju kompleksnog fenomena poduzetništva. Teorijski okvir istraživanja nalazi se u Bourdieuovoj teoriji prakse. Bourdieuova metodologija, za razliku od svih metodoloških monizama koji pridaju ontološko prvenstvo strukturi ili akciji, sistemu ili akteru, kolektivu ili individuumu, inzistira na prvenstvu odnosa - njegova je metodologija relacionistička (Fanuko, 2008., str. 11) što omogućuje sveobuhvatno sagledavanje procesa umjesto partikularnog pristupa u istraživanjima. Iako u Europskoj uniji kreativne i kulturne industrije čine jedan od najdinamičnijih sektora gospodarstva (Rašić Bakarić, Bačić, Božić, 2015.), Hrvatska u ovom sektoru još uvijek zaostaje za razvijenim zemljama, a ciljevi za budućnost kulturne i kreativne industrije trebali bi biti osnaživanje postojećih djelatnosti i međunarodno umrežavanje (Ahmetašević, 2015., str. 88). Ciljevi istraživanja su identificirati vrste kapitala koje koriste poduzetnici u kreativnim i kulturnim industrijama u Hrvatskoj te ispitati mogućnosti konverzije kapitala iz jednog oblika u drugi. Postavljena su dva istraživačka pitanja. Prvo istraživačko pitanje glasi: Zašto poduzetnici u kreativnim i kulturnim industrijama pretvaraju kapital iz jednog oblika u drugi?, dok je drugo istraživačko pitanje: Kako poduzetnici u kreativnim i kulturnim industrijama pretvaraju kapital iz jednog oblika u drugi? Motivacija za istraživanje poduzetnika u kreativnim i kulturnim industrijama proizlazi iz istraživačke znatiželje vezane uz specifičnosti ove vrste poduzetnika s obzirom na postojanje kreativnog, nerijetko i umjetničkog habitusa poduzetnika uz istodobnu potrebu postizanja ekonomske održivosti i ispunjavanja potreba tržišta. Također, GEM istraživanje za Republiku Hrvatsku (GEM - Global Entrepreneurship monitor) više je puta naglasilo kako hrvatska poduzeća već dulji niz godina mnogo ulažu u najnovije tehnologije, no rezultat tih ulaganja se ne očitava u rastu novih proizvoda i usluga (Singer, Šarlija, Pfeiffer i Oberman Peterka, 2018.). Slično konstatiraju i Prester, Podrug i Daraboš (2015.) naglašavajući da sami viši iznosi ulaganja u istraživanje i razvoj ne moraju rezultirati novim proizvodima, nego je za stvaranje inovacija važno da se kreativnošću stvaraju nova znanja i da se ta znanja aktivno koriste u stvaranju inovacija. Posljedica slijeđenja ideje da će tehnološka opremljenost sama po sebi rezultirati 
inovacijama jest stagniranje Hrvatske na ljestvicama konkurentnosti. (Singer i sur., 2018.). Stojčić, Hashi i Aralica (2018.) koncizno su sumirali niz argumenata iz literature o važnosti kreativnih industrija za uspješne ekonomske rezultate regionalnih i nacionalnih gospodarstava. Utjecaj se ostvaruje kroz stvaranje eksternalija na povezane djelatnosti gdje dolazi do prelijevanja praksi otvorenih inovacija i mobilnosti radne snage, a za Hrvatsku je također istraživanjima potvrđena važnost kreativnih industrija za kulturu i društvo.

Ovo istraživanje predstavlja nastavak istraživanja o utjecaju socijalnog kapitala na stvaranje ekonomskog kapitala u kreativnim i kulturnim industrijama (Fojs, Vuković i Detelj, 2017.). Prema saznanjima autorica u Hrvatskoj dosad nije bilo empirijskih istraživanja poduzetništva uz korištenje fenomenološkog pristupa. Kvalitativne metode općenito su manje zastupljene u istraživanjima poduzetništva u Hrvatskoj (Vuković, Šmaguc i Detelj, 2018.). Doprinos ovog istraživanja je dvostruk: s jedne strane predstavlja novi, kvalitativni pristup u istraživanju kreativnih i kulturnih industrija u Hrvatskoj dubinskim pristupom realnom životu poduzetnika, a s druge strane daje doprinos izoštravanju teorije kapitala putem ispitivanja mogućnosti konverzije kapitala u određenom kontekstu, kako industrijskom tako i društveno-ekonomskom. U interpretativnom pristupu izgradnja teorije (kao i profinjenje, odnosno izoštravanje teorije i koncepata) može se shvatiti kao evolutivni i iterativni postupak kontinuiranog unaprjeđenja teorije kroz primjenu u novim kontekstima (Cope, 2005.). Kao takva, ,gusta deskripcija“ (Geertz, 1973.) igra važnu ulogu u izgradnji i/ili dogradnji teorije.

\section{BOURDIEUOVA TEORIJA KAPITALA}

Iako se prepoznavanje važnosti ne samo fizičkih stavaka imovine za stvaranje vrijednosti u poduzećima može prepoznati u prvim člancima o intelektualnom kapitalu početkom devedesetih godina 20. stoljeća koji su izazvali veliko zanimanje stručne javnosti (Kolaković, 2003.), naš izbor teoretskog koncepta ipak je pao na mnogo razrađeniju Bourdieuovu teoriju kapitala sa samoga kraja tog desetljeća. Prepoznajući značenje materijalnih i nematerijalnih resursa za mala poduzeća, istraživači počinju koristiti Bourdieuovu teoriju kapitala kako bi istražili raznolikost resursa koje angažiraju mali poduzetnici (Stringfellow, Shaw i Maclean, 2014.; Pret i sur., 2016.). Kapital prema Bourdieu (1997.) ima četiri forme: ekonomski kapital, kulturni kapital, socijalni kapital i simbolički kapital. Pojedinac koristi kapital kako bi slijedio i provodio svoje životne projekte. Ekonomski kapital odnosi se na novac, odnosno novčani dohodak kao i druge financijske resurse i imovinu, materijalnu ili nematerijalnu, sve ono što netko posjeduje a moguće je pretvoriti u 
novac. Očito je da stvaranje ekonomskog kapitala ima značajnu težinu u poduzetničkom procesu. To nam je ujedno i podsjetnik da je motivacija za poduzetništvo obično vezana uz stvaranje ekonomskog bogatstva kao pokretača poduzetničkih aktivnosti. No, motivacija može biti vezana i uz utjecaj na društveno obogaćivanje i promjene u kontekstu socijalnog života. Konceptualizacija kulturnog kapitala je kompleksnija jer identificira tri tipa kulturnog kapitala: utjelovljeni kulturni kapital, koji se odnosi na osobne dispozicije pojedinca, potom opredmećeni kapital koji se javlja u obliku kulturnih dobara te institucionalizirani kulturni kapital koji se prije svega odnosi na formalno društveno priznanje u obliku stečenog stupnja i vrste obrazovanja (McLeod, O’Donohoe i Townley, 2009.). Socijalni kapital predstavlja pojedinčev sustav veza i odnosa koje on uspostavlja s pojedincima iz svoje uže ili šire okoline. Simbolički kapital nije posebna vrst kapitala već je izveden iz ekonomskog, kulturnog ili socijalnog. Sva tri navedena tipa kapitala mogu se (a i ne moraju) transformirati u simbolički kapital onda kad ih se opaža i priznaje kao legitimne. Simbolički kapital uključuje pokazatelje povjerenja i uvjeravanje drugih da ekonomski, kulturni i socijalni kapital koje posjeduje poduzetnik ili poduzeće imaju legitimitet i kredibilitet (De Clercq i Voronov, 2009.). Priznavanje legitimiteta i kredibiliteta poduzetnika i poduzeća može se odnositi na kupce, partnere ili investitore te mogu biti opredmećeni u formi priznanja i prepoznatljivosti u javnosti (Pret i sur., 2016.). Važan aspekt Bourdieuove teorije kapitala jest stajalište da je svaka forma kapitala konvertibilna, odnosno da je promjenjiva u druge forme kapitala (Pret i sur., 2016.). Konvertibilnost kapitala može biti krucijalna za uspjeh, osobito kad se radi o malim poduzećima s ograničenim financijskim resursima (Drakopoulou Dodd, Pret i Shaw, 2016.).

Ukratko bi se Bourdieuova teorija mogla opisati kao napor da se objasni različite vrste resursa (kapitala) koje pojedinac angažira da bi poduzeo određenu strategiju te kako je strategija rezultat pregovaranja i oblikovanja habitusa ${ }^{1}$ kao logike polja, tj. socijalnih struktura što dovodi do promjene polja pod utjecajem djelovanja pojedinca (Forson, Ozbilgin, Ozturk i Tatli, 2014.). Bourdieuova djela ukazuju na aktivan napor da se objedine empirijske specifičnosti i razvoj teorije.

1 Habitus je sintetički naziv za mnoštvo pojedinačnih iskustava koja su formirala određeni tip subjektivnosti (Sorić, 2012.), a polje Bourdieu definira kao relacijski, dinamički društveni mikrokozmos koji se neprestano mijenja, što povlači za sobom da je polje opisano relacijskim i dijalektičkim pojmovima (Bourdieu i Wacquant, 1992.). 
K. VUKOVIĆ, I. FOJS, K. DETELJ: Konverzije kapitala poduzetnika u kreativnim i kulturnim industrijama... EKONOMSKI PREGLED, 72 (4) 597-618 (2021)

\section{METODOLOŠKI OKVIR ISTRAŽIVANJA}

\subsection{Filozofske postavke istraživanja - istraživačka paradigma}

U ovom radu koristi se interpretativna paradigma temeljena na fenomenološkom pristupu u istraživačkom postupku prikupljanja i analize empirijskog materijala. Prikupljanje podataka putem fenomenološkog intervjua omogućuje slaganje „fotografskih isječaka“ (Lincoln i Guba, 1985.) života utjelovljenih u višestrukim studijama slučajeva. Upravo to je ono što suštinski razlikuje fenomenološku metodu od pozitivističkih i funkcionalističkih metoda (Cope, 2005.). Osnovni cilj interpretativne fenomenološke analize je detaljno istražiti kako sudionici konstruiraju smisao i značenje, odnosno kako oblikuju svoj osobni i društveni svijet te tako dobiti uvid u posebna iskustva, događaje i stanja aktera određenog interakcijskog konteksta (Halmi, 2005., str. 389.). Fenomenološki pristup istraživanjima zastupljen je u društvenim znanostima, osobito u sociologiji i psihologiji, a začetnik ,fenomenološkog pokreta“ je filozof Edmund Husserl2 (1859.-1938.) (Cope, 2005., str. 164.). Dok je u tradicionalnoj pozitivističkoj ontologiji istraživač neovisan o realnosti koja se nalazi „negdje izvan“ te ignorira probleme i istraživačka pitanja koja ne odgovaraju pozitivističkom dizajnu, u interpretativnom pristupu uzima se u obzir kompleksna filozofska debata o tome što tvori realnost ${ }^{3}$ te postavljaju epistemološka pitanja o onome što se zna i što može biti spoznato (Eisenhardt, 1989.). Iako fenomenološki pristup pretpostavlja ,redukciju“ dosadašnjih navika u iskustvu i mišljenju istraživača (Halmi, 2005.), u praksi je „čisti“ fenomenološki pristup često teško primijeniti (Cope, 2005.). Pritom je bitna umješnost istraživača u održavanju ravnoteže između što manjeg uplitanja u riječ ispitanicima i vođenje razgovora u smjeru dobivanja odgovora na istraživačka pitanja kroz dubinski, ,fleksibilno“ strukturirani intervju (Cope, 2005.). U takvom istraživanju ne teži se udovoljiti tradicionalnim pozitivističkim kriterijima pouzdanosti, objektivnosti i generalizacije već se nastoji razumjeti i prikazati što stoji u pozadini tog procesa kroz kriterije kredibilnosti, transferabilnosti, ovisnosti i potvrdivosti (Lincoln i Guba, 1985., str. 189.).

2 Husserlove ideje utjecale su na stvaranja fenomenološke sociologije A. Schutza (1899.1959.) po kojem ljudi konstruiraju socijalnu stvarnost dok je teorija ličnosti koju je postavio Carl Rogers primjer fenomenološkog pristupa u psihologiji prema kojem druge osobe mogu proučavati nečiji privatni svijet jedino ako pokušamo svijet percipirati onako kako ga percipira pojedinac (Halmi, 2005., str. 108.)

3 Za kvalitativne istraživače stvarnost čine akteri koji su participativno uključeni u istraživanje, a višestruka stvarnost može se interpretirati iz perspektive svih sudionika u istraživanju zbog čega istraživači u svojim znanstvenim prikazima istraživanja interpretiraju stvarnost koja počiva na „glasovima drugih“ (Halmi, 2005., str. 37.) 


\subsection{Uzorak}

U odabiru ispitanika korištena je metoda svrhovitog uzorkovanja kako je opisuje Patton (1990.) kako bi se odabrali „slučajevi bogati informacijama“ za potrebe dubinske analize slučajeva. Dijelom je korištena metoda snježne grude jer su na taj način identificirani slučajevi interesantni za istraživanje putem trećih osoba koje su ih preporučile kao dobre primjere za ovo istraživanje. Iako ispitanici nisu birani tako da budu reprezentanti različitosti pojedinih poduzetnika, korišteni su određeni kriteriji odabira ispitanika. U uzorku su profitno orijentirani poduzetnici, otvoreni za korištenje novih prilika i internacionalizaciju poslovanja. Ispitanici dolaze s područja grada Varaždina (9 ispitanika) i Zagreba (1 ispitanik).

Djeluju u deset različitih djelatnosti iz polja kreativnih i kulturnih industri$\mathrm{ja}^{4}$ (biranih prema statističkoj procjeni opsega kreativne ekonomije u Republici Hrvatskoj, Rašić Bakarić i sur., 2015.), a obujmom poslovanja spadaju u red mikropoduzetnika. Iako su neke dimenzije varijabilnosti uključene u uzorak, ispitanici su prije svega odabrani zbog jedinstvene i zanimljive priče koju su mogli unijeti u proces istraživanja. Kontrastiranje i kompariranje (različite djelatnosti, različite dobne skupine poduzetnika, različita širina tržišta, različiti pravni oblici djelovanja) omogućuju upoznavanje s bogatstvom i raznolikošću poduzetničkih praksi angažiranja različitih vrsta kapitala i njihove konverzije iz jednog oblika u drugi sa svrhom postizanja legitimiteta i kredibiliteta u specifičnom polju djelovanja. U odabiru broja ispitanika korišteni su savjeti istraživača (Smith, 2004.; Palinkas, Horwitz, Green, Wisdom, Duan i Hoagwood, 2015.; Pret i sur., 2016.) te je za ovo fenomenološko ispitivanje odabrano 10 jednokratno intervjuiranih ispitanika (u slučaju višekratnog intervjuiranja preporuka je 3-6 ispitanika).

\subsection{Prikupljanje podataka}

Istraživanje je provedeno tijekom veljače, svibnja i lipnja 2017. godine. Intervjui su započinjani otvorenim pitanjima poput: „Recite nešto o tome kako je nastalo poduzeće“ ili „Recite nešto o djelatnosti kojom se bavite“. Prednost fe-

4 Djelatnosti obuhvaćene istraživanjem su redom: izdavaštvo i usluge u izdavaštvu, modni dizajn, šivanje i izrada torbica, izrada ilustracija, grafički dizajn, proizvodnja keramike i lončarskih proizvoda, odnosi s javnošću, priopćavanje, audiovizualna djelatnost, odgoj i obrazovanje mladih filmskih stvaratelja vezano uz animirani film, ples, organizacija plesnih priredbi, organizacija plesnih natjecanja, fotografija i popratne djelatnosti, slikarstvo, dizajn, umjetnička djelatnost, slikarstvo i obrada stakla. 
nomenološkog intervjuiranja je neoptruzivnost u prikupljanju podataka što povećava realnost i valjanost prikupljenih podataka (Mužić, 2004.). Radi što ugodnije atmosfere za ispitanike razgovori su se obavljali u prostorima njihovih radionica, ateljea, galerija, ureda ili mirnih kafića, a koristio se svakodnevni razgovorni jezik (Patton, 1990.). Ispitanicima je osigurana povjerljivost i anonimnost, a svi su ispitanici dobrovoljno pristali na snimanje razgovora kako bi se u analizi zvučni zapis intervjua mogao pretvoriti u doslovne transkripte. Razgovori su trajali u prosjeku 50 minuta, a prikupljeni materijal pretvoren u transkripte iznosi 145 stranica teksta jednostrukog proreda. Osim prikupljanja materijala putem intervjua, tijekom istraživanja prikupljali su se i ostali dostupni podaci poput službenih internetskih stranica poduzeća i sadržaja generiranih prisutnošću poduzetnika na društvenim mrežama čime se produbljuje razumijevanje poduzetničke prakse (Pret i sur., 2016.) i povećava razina potvrdivosti istraživanja (Lincoln i Guba, 1985.).

\subsection{Analiza podataka}

U analizi prikupljenih podataka poštovali su se principi interpretativne fenomenološke analize (Cope, 2011.). Početna faza u analizi podataka fenomenološkog istraživanja uključuje izradu transkripata pri čemu su snimljeni intervjui u cijelosti pretočeni u doslovan pisani tekst razgovora. Uz izradu transkripata počinje inicijalna analiza kroz ,upoznavanje“ sa svakim sudionikom istraživanja. Svaki je transkript pročitan više puta od strane dviju istraživačica kako bi se umanjio utjecaj subjektivnosti imanentan kvalitativnim istraživanjima. Tijekom čitanja na marginama teksta ispisivane su detaljne bilješke koje naglašavaju potencijalno značajna iskustva i probleme (Patton, 1990.). Bilješke su sadržavale otvorene kodove koji su u kasnijoj fazi analize teksta pretočeni u sustav subordiniranih i superordiniranih kategorija (Smith, Flowers i Larkin, 2009.). Ovaj sustav nastao je nakon otkrivanja i kodiranja tema unutar svakog zasebnog slučaja te uspoređivanja slučajeva i traganja za modelom u kojem bi se razvio odgovarajući sustav kategorija. U ovom članku iznosi se dio rezultata istraživanja koji se odnosi na vrste kapitala kojima se poduzetnici služe te konverzije kapitala pa je sustav kategorija vezan uz različite forme pojedinih vrsta kapitala, konverzije kapitala i identificiranje pospješivača (facilitatora) te usporivača (inhibitora) konverzije kapitala. 


\section{REZULTATI I DISKUSIJA}

Kroz postupak kodiranja prepoznati su i kao koncepti razvrstani oblici kapitala (u Tablici 5 u prilogu ovog članka nalaze se primjeri kodova nastali analizom empirijskog materijala). Ekonomski kapital uključuje financijsku imovinu (prihod, ušteđevina, poticaji), neopipljivu imovinu (dizajn, intelektualno vlasništvo), opipljivu imovinu (oprema, materijal, prostor, zalihe). Kulturni kapital čine utjelovljeni kulturni kapital (iskustvo, znanje, vještine), institucionalizirani kulturni kapital (obrazovanje, treninzi/edukacije) te opredmećeni kulturni kapital (obrtnički proizvodi). Socijalni kapital čine: poslovne veze (udruženja, grupe podrške), privatne veze (obitelj, prijatelji), sljedbenici (online pratitelji), kolege (proizvođači, profesori), učenici (naučnici). Simbolički kapital poduzetnika nalazi se u certifikatima i nagradama, izložbama, medijskoj pokrivenosti (članci u časopisima, online prikazi), reputaciji (povjerenje kupaca, recenzije, filantropija). Nakon identificiranja oblika kapitala ispitane su mogućnosti konverzije ekonomskog, kulturnog, socijalnog i simboličkog kapitala.

\subsection{Konverzije ekonomskog kapitala}

Iako se ekonomski kapital u literaturi nerijetko ističe kao najkritičniji oblik kapitala za mala poduzeća (Brinckmann, Salomo i Gemuenden, 2011.) te se smatra da je proces transformacije ekonomskog kapitala u kulturni, socijalni i simbolički kapital kompleksan i zahtijeva puno uloženog vremena (Jayawarna, Jones i Macpherson, 2014.), percepcija poduzetnika o značenju pojedinih oblika kapitala ukazuje da poduzetnici u kreativnim i kulturnim industrijama ne daju primat ekonomskom kapitalu već da sve vrste kapitala smatraju podjednako važnima (Fojs i sur., 2017.). U Tablici 1. navedeni su primjeri su konverzije ekonomskog kapitala u kulturni, socijalni i simbolički kapital iz empirijskog materijala prikupljenog tijekom ovog istraživanja. Ulaganje u kulturni kapital ne mora značiti uvijek velike iznose uložene u elitno obrazovanje koje donosi mogućnost umrežavanja u prestižnim krugovima kako to sugeriraju neki izvori (Randle, Forson i Calveley, 2015.). 
Tablica 1.:

\section{KONVERZIJE EKONOMSKOG KAPITALA}

\begin{tabular}{|l|l|}
\hline \multicolumn{2}{|c|}{ Konverzija ekonomskog kapitala } \\
\hline Kulturni kapital & $\begin{array}{l}\text { „Bilo je dosta ulaganja u sebe same, znači imamo u timu } \\
\text { ilustratoricu koja je uložila u obrazovanje, u učenje grafičkih } \\
\text { programa i tu smo zapravo ušli u ovu izdavačku branšu...“ } \\
\text { (Ispitanica 1) }\end{array}$ \\
\hline $\begin{array}{l}\text { - „... još sam bila u srednjoj, jedna žena iz Francuske, poznata } \\
\text { vezilja, bila je na toj nekoj turneji po Hrvatskoj, platili smo } \\
\text { nekih petnaest eura...“ (Ispitanica 3) }\end{array}$ \\
\hline Socijalni kapital & $\begin{array}{l}\text {, „U Hrvatskoj obrtničkoj komori članstvo je obavezno, mislim } \\
\text { obavezna su plaćanja tih članarina...“ (Ispitanica 2) }\end{array}$ \\
\hline Simbolički kapital & $\begin{array}{l}\text { „Između 20 i 50 eura moraš platiti da se prijaviš. Na primjer, } \\
\text { kažu mi daj fotografiju za National Geographic, a na njega se } \\
\text { prijavi 100.000.000 fotografija s cijelog svijeta.“ (Ispitanik 8) }\end{array}$ \\
\hline
\end{tabular}

Izvor: vlastito istraživanje

U pogledu konverzije ekonomskog kapitala u socijalni, indikativan je izostanak eksplicitno iskazane koristi od članstva u nacionalnim strukovnim udruženjima što ukazuje na postojanje inhibitora pretvorbe članarine (navedeni primjer Hrvatske obrtničke komore) u korist za poduzetnike.

Poduzetnici ponekad smatraju da je potrebno platiti previsoku cijenu da bi se došlo do simboličkog kapitala poput reputacije (Ispitanik 8: „Ti moraš platiti do 10.000 kuna za izložbu da bi netko rekao, bravo, potapša te po ramenu. To je samo ego, ne treba mi to."). Ovo je usporedivo s uočenim inhibitorom pretvorbe ekonomskog u drugu vrst simboličkog kapitala, filantropiju, jer dobrotvorne aktivnosti također mogu zahtijevati značajna sredstva da bi se održala reputacija (Shaw i sur., 2013.). Poduzetnici u kreativnim i kulturnim industrijama u Hrvatskoj pokazuju sklonost humanitarnim aktivnostima, no ne traže na taj način put do reputacije već to rade individualno (,Znamo ovako samoinicijativno humanitarno djelovati“", Ispitanica 1) i iz altruističkih razloga (,,... meni su bitne te, ne prividne humanitarne akcije, nego konkretno za konkretne rezultate. Društvena aktivnost je vrlo bitna.“, Ispitanica 9).

U pogledu nematerijalne imovine, vrlo bitne u kreativnim i kulturnim industrijama zbog specifičnosti proizvoda koji uključuje u velikoj mjeri estetsku dimenziju i kulturno-kreativne dispozicije proizvođača te u literaturi istaknute potrebe za zaštitom intelektualnog i industrijskog vlasništva proizvođača, dolazi 
se do zanimljivih rezultata u vidu percepcije ispitanika o značenju pravne zaštite proizvoda. Dok je potreba nekih ispitanika za zaštitom autorskih prava samorazumljiva i nužna (Ispitanica 1), postoji i stav da je kreativnost neograničeni resurs te da konkurenti kopiranjem ne mogu naštetiti proizvođaču koji ima dovoljno dobrih ideja koje može komercijalizirati (Ispitanik 8). Izostanak zaštite autorskih prava može biti također i dio svjesne i namjerne poslovne strategije jer posudbom kreativnih ideja proizvodima drugih proizvođača ostvaruju svoje ciljeve pretvorbom utjelovljenog kulturnog kapitala u ekonomski i simbolički (Ispitanica 9).

S obzirom na kompleksan odnos institucija i poduzetnika u Hrvatskoj i percepciju poduzetnika o izostanka potpore, financijske i nefinancijske (Šmaguc i Vuković, 2017.), dio ispitanika ipak ističe stanovitu potpornu ulogu lokalnih vlasti (prostor i sl.), dok je percepcija koristi od poduzetničke infrastrukture (tehnološki park, centar za kreativne industrije, razvojna agencija) različita. Za neke ispitanike postojanje poduzetničke infrastrukture na lokalnom području predstavljalo je facilitator konverzije kapitala, dok za neke ispitanike to nije bio slučaj.

\subsection{Konverzije kulturnog kapitala}

Značenje kulturnog kapitala od osobitog je značenja u kreativnim i kulturnim industrijama (Pret i sur., 2016.; Mcleod i sur., 2009.; Townley, Beech i Mckinlay, 2009.). Naime, proizvodi kreativnih i kulturnih industrija specifična su kombinacija estetske i tržišne komponente s obrzirom da kreativne aktivnosti ,generiraju proizvod" te takvi proizvodi predstavljaju utjelovljenje kreativnog procesa i kulturnog kapitala (Townley i sur., 2009., str. 946.). U Tablici 2. Nalaze se primjeri konverzije kulturnog kapitala u ekonomski, socijalni i simbolički kapital oslikani pomoću isječaka razgovora s ispitanicima. Stvaranje proizvoda u kreativnim i kulturnim industrijama nerijetko proizlazi iz umjetničko-kreativnog habitusa pojedinca koji se svjesno ili spontano pretvara u ekonomski kapital (,... iz hobija sam se počela baviti s tim, ... i onda kako su se narudžbe počele stvarati i povećavati, tako sam ja iznajmila jedan prostor ....”, Ispitanica 4). 
Tablica 2.:

KONVERZIJE KULTURNOG KAPITALA

\begin{tabular}{|c|c|}
\hline \multicolumn{2}{|r|}{ Konverzija kulturnog kapitala } \\
\hline Ekonomski kapital & $\begin{array}{l}\text { - „... mi imamo neka specifična znanja koja ne postoje na } \\
\text { tržištu i to se da dobro unovčiti ...“(Ispitanica 6) } \\
\text { • „,... festival konkretno je proizvod, možemo staviti na } \\
\text { tržište...“ (Ispitanica 6) }\end{array}$ \\
\hline Socijalni kapital & $\begin{array}{l}\text { - „,... u Centru kreativne industrije smo osam godina, znate, } \\
\text { nekak mi bolje odgovara biti okružena ljudima.“ (Ispitanica } \\
\text { 4) } \\
\text { - „... održavam radionice, izložbe, uglavnom edukativne } \\
\text { radionice, učim djecu crtati, a i odrasle, ovisi o interesu ...“ } \\
\text { (Ispitanica 10) }\end{array}$ \\
\hline Simbolički kapital & $\begin{array}{l}\text { - „Humana Nova uzima moje slikice na svoje torbe i svi } \\
\text { percipiraju da su to moje torbe...“ (Ispitanica 9) } \\
\text { - „Dobila sam preko Akademije posebnu Rektorovu nagradu za } \\
\text { umjetničke radionice za djecu sa otoka Visa...“ (Ispitanica 10) }\end{array}$ \\
\hline
\end{tabular}

Izvor: vlastito istraživanje

U poimanju uloge formalnog obrazovanja ispitanici se razlikuju. Neki smatraju formalno obrazovanje jako bitnim (,... Akademija nosi svoje - to je ko' da poliraš neku svoju percepciju, bez fakulteta ljudi nemaju smjernice, nemaju viziju, imaju, ali možda ne te razine koju steknu obrazovanjem na sveučilištu.“, Ispitanica 10). Drugi ispitanici nedostatak formalnog obrazovanja ističu kao inhibitor pretvorbe u druge vrste kapitala npr. u simbolički kapital (,... htjela sam dobiti certifikat tradicijskog ili umjetničkog obrta, tradicijskog nisam mogla dobiti jer ne radim uporabne tradicijske predmete, a umjetnički ne mogu dobiti zbog toga jer nemam obrazovanje za to... Znači da onda Van Gogh nije umjetnik? Jer nema verificirano obrazovanje?“, Ispitanica 4). Ističe se vrijednost kroz praksu stečenih vještina (... oni tamo imaju koncept da je dizajner onaj koji samo crta... to je onak, početak, a nakon toga moraš to razraditi, rukama, da si vizualiziraš, samo da to stvoriš...", Ispitanica 3). Poduzetnici u kreativnim industrijama skloni su također samoučenju i eksperimentiranju (Marvel, Davis i Sproul, 2016.) što pokazuje i ovo istraživanje (,,.. znači o keramici nisam znala apsolutno ništa, do te mjere da sam ja mislila da se to može peći u pećnici... mene je to jako interesiralo i ja sam si radila nekakve stvari...", Ispitanica 4). U konverziji kulturnog kapitala u simbolički kod poduzetnika u kreativnim i kulturnim industrijama opaža se izgradnja reputacije kroz razvoj individualnog stila (Pret i sur., 2016.). Na taj se način smanjuje 
rizik imitacije i jača njihova kompetitivnost i diferencijacija proizvoda (Tan, Shao i Li, 2013.). To potvrđuju i ispitanici u hrvatskom istraživanju (,Svaka moja stvar je autorsko djelo, rijetko kad ima dva ili tri, uglavnom su unikati...", (Ispitanica 2); „... tko drži do sebe, neće me kopirati, iako ima jedan s istim imenom, a čovjek konstantno koristi moj nickname.“, (Ispitanik 8).

\subsection{Konverzije socijalnog kapitala}

Jake veze (Putnam, 2001.), odnosno povezujući socijalni kapital Granovetter (1973., 1985.) unutar obitelji i krugova prijatelja predstavljaju značajan potencijal za pretvorbu u ekonomski kapital (,Kad sam bila u srednjoj još, onda smo počeli kupovati mašine, tata je, pošto on se isto bavio s tim prije...", Ispitanica 3). U Tablici 3. nalaze se primjeri konverzije socijalnog kapitala u ekonomski, kulturni i simbolički. Literatura ukazuju na brojne primjere međusobnog učenja koje omogućuje socijalni kapital (Karataş-Özkan, 2011.; Leitch, McMullan i Harrison, 2013.). U ovom istraživanju također je vidljivo kako poduzetnici zajedno stvaraju novi kulturni kapital. („Sastajemo se s vremena na vrijeme poduzetnici iz turističkih voda, do umjetnika i onda pokušavamo iskemijati razne programe i sadržaje... jedni druge potičemo, usmjeravamo i jedni drugima budemo podrška.“ , Ispitanica 5). 
K. VUKOVIĆ, I. FOJS, K. DETELJ: Konverzije kapitala poduzetnika u kreativnim i kulturnim industrijama... EKONOMSKI PREGLED, 72 (4) 597-618 (2021)

Tablica 3.:

\section{KONVERZIJE SOCIJALNOG KAPITALA}

\begin{tabular}{|c|c|}
\hline \multicolumn{2}{|r|}{ Konverzija socijalnog kapitala } \\
\hline Ekonomski kapital & $\begin{array}{l}\text { - „... znaju dizajnerice ove varaždinske, rade haljine za } \\
\text { maturalne, onda ih znaju poslati k nama, za torbu da im ide uz } \\
\text { haljinu...“ (Ispitanica } 3 \text { ) } \\
\text { - }, \ldots \text { od mojeg plesnog partnera mama je imala mogućnost } \\
\text { neka sponzorstva naći ...“ (Ispitanica 7) } \\
\text { - „... obavezno umrežavanje s kolegama,... svatko svoje radi, } \\
\text { svatko ima svoje, onda ne dolazi do tenzija i financijski se } \\
\text { jasno zna kome kaj pripada.“ (Ispitanica 9) }\end{array}$ \\
\hline Kulturni kapital & $\begin{array}{l}\text { - „... da sam danas napravila takvu slikovnicu kakva je, to mi } \\
\text { je kolega unutar udruge određene savjete dao...“ (Ispitanica } \\
\text { 9) } \\
\text { • „... sva ta umreženost omogućuje umjetniku kreiranje novih } \\
\text { proizvoda za industriju, u zaštićenom prostoru.“ (Ispitanica 9) } \\
\text { - „... zapravo suprug me naučio lemiti nitne...“ (Ispitanica 3) } \\
\text { - „... pa definitivno bih tu stavila svojeg profesora Antuna } \\
\text { Vrlića, on mi je približio to staklo...“ (Ispitanica 10) }\end{array}$ \\
\hline Simbolički kapital & $\begin{array}{l}\text { - „... nazvao nas je da se preko njih reklamiramo, pa smo bili } \\
\text { tamo, to je jedan alternativni časopis...“ (Ispitanica 4) } \\
\text { - „Prava povratna informacija je to da udruga trideset godina } \\
\text { već ima kod svakog upisa veliki broj članova.“ (Ispitanica 6) } \\
\text { - „,... u konstantnom smo kontaktu s njima. Isto tako, te } \\
\text { internacionalne instruktore zovemo kod nas da rade različite } \\
\text { radionice...“ (Ispitanica 7) }\end{array}$ \\
\hline
\end{tabular}

Izvor: vlastito istraživanje

Potporne mreže eksperata omogućuju pristup informacijama vezanim uz poslovanje i izradu proizvoda (,Savjet uvijek možeš dobiti [od stručnih organizacija], možeš nazvati i tražiti savjet...", Ispitanica 7).

Nedostatak simboličkog kapitala moguće je nadoknaditi povezanošću s dobro pozicioniranim osobama (npr. u medijima) što omogućuje pristup široj publici (,... pošto je sestra radila u novinama, pa je imala dosta kontakta s medijima, onda je bilo tu nekih portala koji su objavili.“, Ispitanica 3). 


\subsection{Konverzije simboličkog kapitala}

Iz Tablice 4. moguće je dobiti uvid o sposobnosti simboličkog kapitala da se transformira u druge oblike kapitala. U skladu s ostalim provedenim istraživanjima opaža se da je reputacija vrlo bitna za stjecanje legitimiteta kod kupaca što se očituje u konverziji simboličkog kapitala u ekonomski kroz povećanje prodaje (Pret i sur., 2016.; Shaw, Lam i Carter, 2008., Zott i Huy, 2007.).

\section{Tablica 4.:}

\section{KONVERZIJE SIMBOLIČKOG KAPITALA}

\begin{tabular}{|l|l|}
\hline \multicolumn{2}{|c|}{ Konverzija simboličkog kapitala } \\
\hline Ekonomski kapital & $\begin{array}{l}\text {,Već dosta dugo smo na tržištu, tako da imamo svoje } \\
\text { deklaracije i privjesnice gdje se vidi proizvođač i onda ljudi } \\
\text { po tome dođu.“ (Ispitanica 4) }\end{array}$ \\
\hline Kulturni kapital & $\begin{array}{l}\text {,Većina je došla po preporuci, znači osamdeset posto ljudi je } \\
\text { po preporuci.“ (Ispitanica 7) }\end{array}$ \\
& $\begin{array}{l}\text {,... odlazila na natjecanja po cijeloj Europi... odlučili smo se } \\
\text { tu stacionirati, otvoriti svoj plesni klub i dalje normalno raditi, } \\
\text { plesati... “ (Ispitanica 7) }\end{array}$ \\
& $\begin{array}{l}\text {,... kad vide da znaš, onda si super i ljudi dijele znanje } \\
\text { jedino kad vide da imaju s kim podijeliti, s vremenom } \\
\text { nemaš vremena za sve, nego se ogradiš s važnim ljudima...“ } \\
\text { (Ispitanik 8) }\end{array}$ \\
\hline Socijalni kapital & $\begin{array}{l}\text {,... onda smo se odlučili na darivanja, jer to ima dosta } \\
\text { shareova i dosta se tako sazna, preko toga, puno cura to } \\
\text { podijeli i komentira.“ (Ispitanica 3) } \\
\text { „Ilustratorica naša ima portfelj na mrežama kao što su } \\
\text { Behance, na internetu pa ju često znaju kontaktirati ne samo } \\
\text { izdavači, nego predstavnici kreativnih industrija iz svih } \\
\text { dijelova svijeta...“ (Ispitanica 1) }\end{array}$ \\
\hline
\end{tabular}

Izvor: vlastito istraživanje

Da bi se izbjegle inhibicije konverziji u ekonomski kapital zbog loše reputacije (Fischer i Reuber, 2007.) ispitanici jako vode brigu o održavanju dobre reputacije (,Ja se jako trudim imati dobru reputaciju, ne dozvolim da proizvod napusti atelje ako ja vidim da nešto nije u redu ili da klijent možda nije zadovoljan.“, Ispitanica 2). Ispitanici ne stavljaju u prvi plan simbolički kapital sam po sebi, već ga vide 
kao potencijal za reprodukciju polja i stvaranje socijalnog i kulturnog kapitala drugih $(, \ldots$ cilj nije natjecanje i tko će bolje, nego je cilj podučiti djecu još jednom svijetu kroz koji se mogu izraziti.“, Ispitanica 6), a ostavljaju otvorenim i pitanje je li simbolički kapital u direktnoj vezi s kulturnim kapitalom, odnosno kvalitetom proizvoda $(, \ldots$ e sad, neki dobe nagradu, neki ne, to je recimo povratna informacija, ali ne mora značiti puno o kvaliteti filma.“, Ispitanica 6). Istraživanje pokazuje značajnu stopu konverzije simboličkog u socijalni kapital, naročito s obzirom na sve veće značenje društvenih mreža putem interneta, ali isto tako ukazuje da je simbolički kapital preduvjet za održavanje postojeće visoke razine socijalnog kapitala (Deephouse i Carter, 2005.).

\section{ZAKLJUČCI I PREPORUKE ZA ISTRAŽIVANJA}

Istraživanje provedeno na području Varaždinske županije i Grada Zagreba ukazuje na velike mogućnosti konverzije kapitala u kreativnim i kulturnim industrijama. U skladu s rezultatima do kojih dolaze Pret i sur. (2016.) i ovo istraživanje pokazuje visoki stupanj konvertibilnosti kulturnog kapitala, no ono po čemu se razlikuju prakse poduzetnika u kreativnim i kulturnim industrijama u odnosu na istraživanje Preta i sur. (2016.) je nešto niži stupanj konverzije simboličkog kapitala, ali viši stupanj konverzije socijalnog kapitala koji u našem društvenom kontekstu ostavlja dojam značajnih mogućnosti korištenja povezujućeg i premošćujućeg socijalnog kapitala.

Različita je i dostupnost pojedinih oblika kapitala za pojedince te njihova percepcija i vrednovanje konverzije kapitala. Iz empirijskog materijala može se nazrijeti da je poduzetnicima izrazito važno djelovanje u više polja - polje djelatnosti, poduzetničko polje, kulturno polje i polje obrazovanja - jer osim poduzetničkog uspjeha vode brigu o reprodukciji polja (edukacije, njegovanje kulturnih navika, stvaranje novih naraštaja konzumenata kulturnih sadržaja i proizvoda u kojima je opredmećena kultura i individualna kreativnost). Nastavak istraživanja može biti dvosmjeran. Jedan pravac može se usmjeriti na istraživanja konverzije kapitala u drugim djelatnostima, izvan kreativnih i kulturnih industrija, kako bi se dao doprinos izoštravanju koncepata kapitala. Kao drugi pravac istraživanja poduzetništva u kreativnim i kulturnim industrijama bilo bi zanimljivo istražiti spomenuta polja djelovanja poduzetnika u kreativnim i kulturnim industrijama kao i karakteristike habitusa poduzetnika u kreativnim i kulturnim industrijama, osobito s obzirom na potrebu pomirbe i balansiranja estetskog i komercijalnog elementa u stvaranju proizvoda i njihovu plasiranju na tržište.

Jedan od uzgrednih rezultata ovog istraživanja nastao je kao posljedica ,skrivene agende“ (Cope, 2005.), a odnosi se na otkrivanje znanja o tome kako poduzet- 
nici u kreativnim i kulturnim industrijama u manjoj urbanoj sredini koriste svoje oskudne resurse i transformiraju jedan oblik kapitala u drugi te kako percipiraju svoju poziciju u mjestu i prostoru s obzirom da se razvoj kreativnih i kulturnih industrija često u literaturi veže uz urbane cjeline „kreativnih gradova“ (Pratt, 2011.). U tom pogledu uviđaju se razlike s obzirom na karakter samog proizvoda/ usluge i mogućnosti korištenja šireg, nacionalnog ili internacionalnog tržišta. U nekim slučajevima izmještenost izvan većih urbanih centara kulturnih i kreativnih aktivnosti (npr. Zagreba) ne predstavlja nikakav inhibitor u komercijalizaciji proizvoda (mogućnost prodaje putem interneta), u drugih je uskoća tržišta i nepraćenje trendova ili izostanak određenih životnih navika od strane potencijalnih korisnika (plesni studio) inhibitor značajnijeg zamaha poslovnih aktivnosti. Neki izmještenost iz glavnog grada ističu kao prednost jer se kroz prepoznatljivost u lokalnoj sredini lakše privlači medijska pozornost na nacionalnoj razini. Odnos mjesta i prostora također može biti jedan od smjerova daljnjeg istraživanja poduzetništva u kreativnim i kulturnim industrijama.

\section{LITERATURA}

1. Ahmetašević, E. (2015.). Razvoj kreativne industrije kroz kulturnu politiku i redefiniranje sustava audiovizualne djelatnosti u Republici Hrvatskoj. Medijska istraživanja, (21), 1: 119-145.

2. Aldrich, H. E. (1992.). Methods in our madness? Trends in entrepreneurship reseach. U: D. L.Sexton i J. D. Kasarda, (Ur.), State of the Art of Entrepreneurship Research (str. 191-213). PWS Kent, Boston.

3. Bourdieu, P. (1997.). The Forms of Capital. U A. H. Halsey, H. Lauder, Ph. Brown i A. S. Wells (Ur.), Education: Culture, Economy, and Society (str. 46-58). Oxford University Press, Oxford.

4. Bourdieu, P. i Wacquant, L. (1992.). An Invitation to Reflexive Sociology. Cambridge: Polity Press

5. Brinckmann, J., Salomo, S. i Gemuenden, H. G. (2011.). Financial management competence of founding teams and growth of new technology-based firms. Entrepreneurship Theory and Practice, (35), 2: 217-243.

6. Cope, J. (2005.). Researching entrepreneurship through phenomenological inquiry: Philosophical and methodological issues, International Small Business Journal, (23), 2: 163-189.

7. Cope, J. (2011.). Entrepreneurial learning from failure: An interpretative phenomenological analyses, Journal of Business Venturing, (26), 6: 604-623. 
K. VUKOVIĆ, I. FOJS, K. DETELJ: Konverzije kapitala poduzetnika u kreativnim i kulturnim industrijama... EKONOMSKI PREGLED, 72 (4) 597-618 (2021)

8. De Clercq, D. i Voronov, M. (2009.). Toward a practice perspective of entrepreneurship: Entrepreneurial legitimacy as habitus, International Small Business Journal, (27), 4: 395-419.

9. Deephouse, D. L. i Carter, S. M. (2005.). An examination of differences between organizational legitimacy and organizational reputation, Journal of Management Studies, (42), 2 :329-360.

10. Drakopoulou Dodd, S., Pret, T. i Shaw, E. (2016.). Advancing understanding of entrepreneurial embeddedness: forms of capital, social contexts and time. U F. Welter i W. Gartner, (Ur.), A Research Agenda for Entrepreneurship and Context (str. 120-133). Cheltenham: Edward Elgar.

11. Eisenhardt, K. M. (1989.). Building Theories from Case Study Research, The Academy of Management Review, (14), 4: 532-550.

12. Fanuko, N. (2008.). Kulturni capital i simbolička moć: tri aspekta Bourdieuove teorije ideologije, Školski vjesnik - Časopis za pedagogijsku teoriju $i$ praksu, (57), 1-2: 7-41.

13. Fischer, E. i Reuber, R. (2007.). The good, the bad, and the unfamiliar: The challenges of reputation formation facing new firms. Entrepreneurship Theory and Practice, (31), 1: 53-75.

14. Fojs, I., Vuković, K. i Detelj, K. (2017.). Impact of Social Capital on the Generation of Economic Capital in Creative Industries. U M. Cingula, M. Przygoda, i K. Detelj (Ur.), $23^{\text {rd }}$ International Scientific Conference on Economic and Social Development Book of Proceedings (str. 678-686). Madrid: Varaždin Development and Entrepreneurship Agency, University North Koprivnica, Management University of Warsaw.

15. Forson, C., Ozbilgin, M., Ozturk, M.B. i Tatli, A. (2014.). Multi-level approaches to entrepreneurship and small business research: transcending dichotomies with Bourdieu. U E. Chell i M. Karataş-Özkan (Ur.), Handbook of Research on Small Business and Entrepreneurship (str. 54-69). Cheltenham: Edward Elgar.

16. Geertz, C. (1973.). The Interpretation of Cultures. New York: Basic Books.

17. Granovetter, M. (1973.). The strength of weak ties, American Journal of Sociology, (78), 6: 1360-1380.

18. Granovetter, M. (1985.). Economic action and social structure: the problem of embeddedness. American Journal of Sociology, (91), 3: 481-510.

19. Halmi, A. (2005.). Strategije kvalitativnih istraživanja u primijenjenim društvenim znanostima. Jastrebarsko: Naklada Slap.

20. Jayawarna, D., Jones, O. i Macpherson, A. (2014.). Entrepreneurial Potential: The role of human and cultural capitals. International Small Business Journal, (32), 8: 918-943. 
21. Karataş-Özkan, M. (2011.). Understanding relational qualities of entrepreneurial learning: Towards a multilayered approach. Entrepreneurship and Regional Development, (23), 9-10: 877-906.

22. Kolaković, M. (2003.). Teorija intelektualnog kapitala. Ekonomski pregled, (54), 11-12: 925-944.

23. Leitch, C. M., McMullan, C. i Harrison, R. T. (2013.). The development of entrepreneurial leadership: The role of human, social and institutional capital. British Journal of Management, (24), 3: 347-366.

24. Lincoln, Y .S., Guba, E. G. (1985.). Naturalistic inquiry. Newbury Park, CA: Sage.

25. Marvel, M. R., Davis, J. L., Sproul, C. R. (2016.). Human capital and entrepreneurship research: A critical review and future directions. Entrepreneurship Theory and Practice, (40), 3: 599-626.

26. McLeod, C., O'Donohoe, S. i Townley, B. (2009.). The elephant in the room? Class and creative careers in British advertising agencies, Human Relations, (62), 7: 1011-1039.

27. Mužić, V. (2004.). Uvod u metodologiju istraživanja odgoja i obrazovanja. Zagreb: Educa.

28. Palinkas, L. A., Horwitz, S. M., Green, C. A., Wisdom, J. P., Duan, N. i Hoagwood, K. (2015.). Purposeful Sampling for Qualitative Data Collection and Analysis in Mixed Method Implementation Research. Administration \& Policy In Mental Health \& Mental Health Services Research, (42), 5: 533 544.

29. Patton, M. Q. (1990.). Qualitative Evaluation and Research Methods. London: Sage.

30. Pratt, A. C. (2011.). The cultural contradictions of the creative city. City, Culture and Society, (2), 3: 123-130.

31. Prester, J., Podrug, N. i Darabosš, M. (2015.). Innovation climate as a source of competitive advantage. Journal of Economic and Social Development, (2), 1: 25-33.

32. Pret, T., Shaw, E. i Drakopoulou Dodd, S. (2016.). Painting the full picture: The conversion of economic, cultural, social and symbolic capital. International Small Business Journal, (34), 8: 1004-1027.

33. Putnam, R. D. (2001.). Social capital: Measurement and consequences. Isuma: Canadian Journal of Policy Research, (2), 1: 41-51.

34. Randle, K., Forson, C. i Calveley, M. (2015.). Towards a Bourdieusian analysis of the social composition of the UK film and television workforce. Work, Employment and Society, (29), 4: 590-606. 
K. VUKOVIĆ, I. FOJS, K. DETELJ: Konverzije kapitala poduzetnika u kreativnim i kulturnim industrijama... EKONOMSKI PREGLED, 72 (4) 597-618 (2021)

35. Rašić Bakarić, I., Bačić, K. i Božić, Lj. (2015.). Mapiranje kreativnih i kulturnih industrija u Republici Hrvatskoj. Zagreb: Ekonomski institut.

36. Shaw, E., Gordon, J., Harvey, C. i Maclean, M. (2013.). Exploring contemporary entrepreneurial philantrophy. International Small Business Journal, (31), 5: 580-599.

37. Shaw, E., Lam, W. i Carter, S. (2008.). The role of entrepreneurial capital in building service reputation. The Sevice Industries Journal, (28), 7: 899-917.

38. Shepherd, D. A. (2015.). Party On! A call for entrepreneurship research that is more interactive, activity based, cognitively hot, compassionate, and prosocial. Journal of Business Venturing, (30), 4: 489-507.

39. Singer, S., Šarlija N., Pfeifer i S., Oberman Peterka S. (2018.). Što čini Hrvatsku (ne)poduzetničkom zemljom?. Global Entrepreneurship monitor Hrvatska 2017. Zagreb: CEPOR.

40. Smith, J. A. (2004.). Reflecting on the development of interpretative phenomenological analysis and its contribution to qualitative research in psychology. Qualitative Research in Psychology, (1), 1: 39-54.

41. Smith, J.A., Flowers, P., Larkin, M. (2009.). Interpretative Phenomenological Analysis: Theory Method and Research. London: Sage.

42. Sorić, M. (2012.). Refleksivnost u sociologiji Pierra Bourdieua: nadilaženje socioloških dihotomija, Soc. ekol. Zagreb, (21), 3: 329-344.

43. Stojčić, N., Hashi, I. i Aralica, Z. (2018.). Creativity, innovations and firm performance in an emerging transition economy. Ekonomski pregled, (69), 3: 203-228.

44. Stringfellow, L., Shaw, E. i Maclean, M. (2014.). Apostasy versus legitimacy: Relational dynamics and routes to resource acquisition in entrepreneurial ventures. International Small Business Journal, (32), 5: 571-592.

45. Šmaguc, T. i Vuković, K. (2017.). Institutional Field in the Republic of Croatia: Perspective of Entrepreneurs Pertaining to Computer Programming Activities. U V. Strahonja i V. Kirinić (Ur.), Central European Conference on Information and Intelligent Systems - 28th International Conference (str. 145-151). Varaždin: Faculty of Organization and Informatics.

46. Tan, J., Shao, Y. i Li, W. (2013.). To be different, or to be the same? An exploratory study of isomorphism in the cluster. Journal of business Venturing, (28), 1: 83-97.

47. Townley, B., Beech, N. i Mckinlay, A. (2009.). Managing in the creative industries: Managing the montley crew. Human Relations, (62), 7: 939-962. 
48. Vuković, K., Šmaguc, T. i Detelj, K. (2018.). Qualitative research in entrepreneurship: Learning how to play the game (str. 812-824). U M. Bozina Beros, N. Recker, Nicholas i M. Kozina (Ur.), Economic and Social Development (Book of Proceedings). Rim: Varazdin Development and Entrepreneurship Agency, Faculty of Management University of Warsaw, University North, Koprivnica.

49. Zott, C. i Huy, Q.N. (2007.). How entrepreneurs use symbolic management to acquire resources. Administrative Science Quarterly, (52), 1: 70-105.

\section{PRILOG}

\section{Tablica 5.:}

OBLICI KAPITALA PODUZETNIKA (,SIROVI“ PODACI)

\begin{tabular}{|c|c|c|}
\hline \multicolumn{3}{|c|}{ Ekonomski kapital } \\
\hline \multirow[t]{3}{*}{$\begin{array}{l}\text { Financijska } \\
\text { imovina }\end{array}$} & Prihod & $\begin{array}{l}\text { - „U odnosu na prvu godinu i sad, prihodi su } \\
\text { porasli za } 60 \text { posto..." (Ispitanica 5) }\end{array}$ \\
\hline & Ušteđevina & $\begin{array}{l}\text { - „Krenule smo s nekakvim vlastitim } \\
\text { sredstvima, ušteđevine, ... stambene štednje, } \\
\text { dionice...“ (Ispitanica 1) }\end{array}$ \\
\hline & Poticaji & $\begin{array}{l}\text { - „Kasnije sam se javljala na poticaje Ministarstva } \\
\text { poduzetništva i na Ministarstvo kulture pa sam } \\
\text { dobivala poticaje.“ (Ispitanica 4) }\end{array}$ \\
\hline \multirow[t]{2}{*}{$\begin{array}{l}\text { Neopipljiva } \\
\text { imovina }\end{array}$} & Dizajn & $\begin{array}{l}\text { - „Svaka moja stvar je autorsko djelo, rijetko } \\
\text { kad ima dva ili tri, uglavnom su unikati“ } \\
\text { (Ispitanica 2) }\end{array}$ \\
\hline & $\begin{array}{l}\text { Intelektualno } \\
\text { vlasništvo }\end{array}$ & $\begin{array}{l}\text { - „U principu, najveću imovinu imamo u } \\
\text { autorskim pravima... ali portal smo zaštitili } \\
\text { kao trade mark.“ (Ispitanica 1) }\end{array}$ \\
\hline \multirow[t]{4}{*}{ Opipljiva imovina } & Oprema & $\begin{array}{l}\text { - „Sav inventar, materijal sve drugo u prostoru } \\
\text { je u mojem vlasništvu ..." (Ispitanica 2) }\end{array}$ \\
\hline & Materijal & $\begin{array}{l}\text { - „... dosta koristim prirodne materijale, često } \\
\text { koristim svilu, nekakve materijale novije, tipa } \\
\text { bambus“ (Ispitanica 2) }\end{array}$ \\
\hline & Prostor & $\begin{array}{l}\text { - „... radim od doma, nemam potrebe za } \\
\text { ulaganjima u prostor, odnosno za plaćanjem } \\
\text { najma...“ (Ispitanica 5) }\end{array}$ \\
\hline & Zalihe & $\begin{array}{l}\text { - „neke modele imamo uvijek, stalno u } \\
\text { zalihama...“(Ispitanica 3) }\end{array}$ \\
\hline
\end{tabular}




\begin{tabular}{|c|c|c|}
\hline \multicolumn{3}{|c|}{ Kulturni kapital } \\
\hline \multirow[t]{3}{*}{\begin{tabular}{|l|} 
Utjelovljeni \\
kulturni kapital
\end{tabular}} & Iskustvo & $\begin{array}{l}\text { - „Radila sam u medijima kao novinar i kasnije } \\
\text { u agenciji za odnose s javnošću.“ (Ispitanica } \\
\text { 1) }\end{array}$ \\
\hline & Znanje & $\begin{array}{l}\text { - „... znanja o animaciji i filmu sam stekla kroz } \\
\text { razne druge radionice.“ (Ispitanica 6) }\end{array}$ \\
\hline & Vještine & $\begin{array}{l}\text { - „... idemo vidjeti i isprobati, mi smo išli sami } \\
\text { praktički sad sve znamo sami napraviti, svaki } \\
\text { dio ...“(Ispitanica 3) }\end{array}$ \\
\hline \multirow[t]{2}{*}{$\begin{array}{l}\text { Institucionalizirani } \\
\text { kulturni kapital }\end{array}$} & Obrazovanje & $\begin{array}{l}\text { - „.... Akademija nosi svoje, bez edukacije, } \\
\text { fakulteta, ljudi nemaju smjernice...“ } \\
\text { (Ispitanica 10) }\end{array}$ \\
\hline & $\begin{array}{l}\text { Treninzi/ } \\
\text { edukacije }\end{array}$ & $\begin{array}{l}\text { - „... nema nikakvih edukacija u smislu nekih } \\
\text { škola, nego različitih plesnih seminara, } \\
\text { kongresa, festivala, radionica.“ (Ispitanica 7) }\end{array}$ \\
\hline $\begin{array}{l}\text { Opredmećeni } \\
\text { kulturni kapital }\end{array}$ & $\begin{array}{l}\text { Obrtnički } \\
\text { proizvodi }\end{array}$ & $\begin{array}{l}\text { - „Izrađujemo na lončarskom kolu, uz pomoć } \\
\text { kalupa, znači potpuno je ručni rad proizvod...” } \\
\text { (Ispitanica 4) }\end{array}$ \\
\hline \multicolumn{3}{|c|}{ Socijalni kapital } \\
\hline \multirow[t]{2}{*}{ Poslovne veze } & Udruženja & $\begin{array}{l}\text { • „ULUPUH Zagreb, Centar kreativne } \\
\text { industrije Graz, Udruženje umjetnika Gornje } \\
\text { Austrije.“ (Ispitanica 9) }\end{array}$ \\
\hline & $\begin{array}{l}\text { Grupe } \\
\text { podrške }\end{array}$ & $\begin{array}{l}\text { - „... živjeli smo u Ljubljani kod tih jako } \\
\text { dobrih plesnih instruktora, oni su i plesni suci, } \\
\text { koji su nam isto dosta pomogli i usmjerili nas, } \\
\text { dali savjete ..." (Ispitanica 7) }\end{array}$ \\
\hline \multirow[t]{2}{*}{ Privatne veze } & Obitelj & $\begin{array}{l}\text { - „,... pošto je sestra radila u novinama, pa je } \\
\text { imala dosta kontakta s medijima...“ (Ispitanica } \\
\text { 3) }\end{array}$ \\
\hline & Prijatelji & $\begin{array}{l}\text { - „Onda jedna prijateljica nam je pripomogla } \\
\text { oko toga da udruga dobije neka mala sredstva } \\
\text { od grada.“ (Ispitanica 6) }\end{array}$ \\
\hline Sljedbenici & $\begin{array}{l}\text { Online } \\
\text { pratitelji }\end{array}$ & $\begin{array}{l}\text { - }, \ldots \text { onda smo se odlučili na darivanja, } \\
\text { jer to ima dosta shareova i dosta se tako } \\
\text { sazna, preko toga, puno cura to podijeli i } \\
\text { komentira..." (Ispitanica } 3 \text { ) }\end{array}$ \\
\hline \multirow[t]{2}{*}{ Kolege } & Proizvođači & \begin{tabular}{|l} 
\\
$\begin{array}{l}\text {,... surađujem sa Glažom, to je obrt za staklo, } \\
\text { treba neki tehnički savjet.“ (Ispitanica 10) }\end{array}$ \\
\end{tabular} \\
\hline & Profesori & $\begin{array}{l}-\ldots \text { za neke tehničke stvari, zovem svog } \\
\text { profesora na Akademiji, on mi je približio to } \\
\text { staklo ili tražim pomoć...“ (Ispitanica 10) }\end{array}$ \\
\hline
\end{tabular}




\begin{tabular}{|c|c|c|}
\hline Učenici & Naučnici & $\begin{array}{l}\text { - „Pa u obrtu je zaposlen moj sin i definitivno je } \\
\text { on osoba koja ce to preuzeti, radimo na tome } \\
\text { da on preuzme taj obrt i dalje...“ (Ispitanica } 4 \text { ) }\end{array}$ \\
\hline \multicolumn{3}{|c|}{ Simbolički kapital } \\
\hline \multirow[t]{2}{*}{$\begin{array}{l}\text { Certifikati i } \\
\text { nagrade }\end{array}$} & Certifikati & $\begin{array}{l}\text { - „... htjela sam dobiti certifikat tradicijskog ili } \\
\text { umjetničkog obrta ...“ (Ispitanica 4) }\end{array}$ \\
\hline & Nagrade & $\begin{array}{l}\text { - „Dobila sam nagradu za najkreativniji } \\
\text { proizvod...“ (Ispitanica 9) }\end{array}$ \\
\hline Izložbe & $\begin{array}{l}\text { Izložbeni } \\
\text { primjerci u } \\
\text { galerijama }\end{array}$ & $\begin{array}{l}\text { - „... imala sam do sad devet samostalnih } \\
\text { izložbi i dosta skupnih, izlagala sam na } \\
\text { skupnim izložbama, osim u Hrvatskoj u } \\
\text { Engleskoj, Slovačkoj, Turskoj, Belgiji i } \\
\text { Mađarskoj.“ (Ispitanica 10) }\end{array}$ \\
\hline \multirow[t]{2}{*}{$\begin{array}{l}\text { Medijska } \\
\text { pokrivenost }\end{array}$} & \begin{tabular}{|l|l} 
Članci u \\
časopisima
\end{tabular} & $\begin{array}{l}\text { - „U medijima sam prilično često prisutna ... } \\
\text { internet portali, lokalne novine ..." (Ispitanica 2) }\end{array}$ \\
\hline & $\begin{array}{l}\text { Online } \\
\text { prikazi }\end{array}$ & $\begin{array}{l}\text { - „.... imamo roditeljski portal, koji koristimo } \\
\text { kao prodajni kanal...“ (Ispitanica 1) }\end{array}$ \\
\hline \multirow[t]{3}{*}{ Reputacija } & $\begin{array}{l}\text { Povjerenje } \\
\text { kupaca }\end{array}$ & $\begin{array}{l}\text { - ,... uvijek se trudim da to bude stvarno dobar } \\
\text { omjer cijene i kvalitete i to mi je jako važno } \\
\text { i mislim da tu imam dobru reputaciju.“ } \\
\text { (Ispitanica 2) }\end{array}$ \\
\hline & Recenzije & • „Recenzije mi pišu stručni ljudi.““ (Ispitanica \\
\hline & Filantropija & $\begin{array}{l}\text { - „... mi smo sami organizirali par } \\
\text { humanitarnih plesnih večeri.“ (Ispitanica 7) }\end{array}$ \\
\hline
\end{tabular}

Izvor: vlastito istraživanje

\title{
THE CONVERSION OF ENTREPRENEURIAL CAPITAL IN CREATIVE AND CULTURAL INDUSTRIES OF NORTWESTERN CROATIA
}

\author{
Summary
}

The aim of this paper is to identify the forms of capital used by entrepreneurs in creative and cultural industries in Croatia and to explore how they convert their capital from one form into the others. The theoretical framework of the research is Bourdieu's capital theory in which capital appears in four forms: economic, cultural, social and symbolic capital. In order to examine the research question, interpretative paradigm has been used with phenomenological interviews as the primary research tool. In-depth interviews with 10 entrepreneurs have been conducted. The results indicate various practices of utilizing entrepreneurial capital and considerable possibilities of capital conversions. Particularly high conversion rates of cultural and social capital have been found.

Key words: Bourdieu's capital theory, creative and cultural industries, entrepreneurs, phenomenological approach 